\section{Gordon E. Baker}

Our long-time colleague Gordon E. Baker passed away on January 13, 2004, a little more than a month after celebrating his 80th birthday. Gordon was born December 6, 1923, in Poughkeepsie, New York, but was raised in Tacoma, Washington.

Gordon was a member of the World War II generation. He received several medals for valor while serving as a corporal in the combat infantry under U.S. Army General "Terrible Terry" Allen in Belgium from 1943 to 1946. After the war he returned to his educationgraduating from Reed College in 1948 - and to a marriage that would last for more than half a century. He received an M.A. from the University of Washington in 1949, did postgraduate work at Brown University, and received his Ph.D. in Politics from Princeton University in 1952 . That same year, Gordon began his teaching career at the University of California, Santa Barbara, in what turned out to be a lifetime appointment. He advanced to full professor in 1965, served as department chair from 1965 to 1971, and became professor emeritus from 1993. He was recalled seven times to teach after retirement, the last time in the winter of 1998.

His most influential work was undoubtedly The Reapportionment Revolution: Representation, Political Power, and the Supreme Court (1966); an earlier book was Rural Versus Urban Political Power: The Nature and Consequences of Unbalanced Representation (1955). Later contributions to the literature on gerrymandering appeared in books edited by Nelson Polsby and Bernard Grofman. He was consulted by court-appointed Masters who redrew the boundaries of California's legislative and congressional districts (a distinction shared by Condoleeza Rice, who-he later said-was not yet in over her head). In subsequent years he served as a consultant and expert witness on reapportionment and related litigation in the states of Wyoming and New York.

An expert on American political thought, Gordon co-authored (with his Princeton mentor Alpheus T. Mason) Free Government in the Making: Readings in American Political Thought (fourth edition, 1985). Gordon's research won support from the Guggenheim Foundation and the Social Science
Research Foundation. In 1979 and again in 1980, grants from the National Endowment for the Humanities funded his direction of special eight-week seminars for college teachers to "work under the supervision of a distinguished scholar"; the acclaim of his students in these seminars recognized his comparable distinction as a teacher. In service to the profession, he was a member of the American Political Science Association's Council from 1968 to 1970, serving on its Executive Committee in 1968-1969.

Gordon was far from a clean-desk man. His close friend Don Balmer of Lewis and Clark College- their association went back to graduate school days at the University of Washington-was recruited to teach at UCSB in the summer of 1979. But his real challenge was to clean out Gordon's office:

I purchased several storage boxes and proceeded to triage the three feet of stuff on every surface. I found envelopes with three-cent stamps on them! Uncashed checks for reimbursement for convention travel, etc. Departmental secretaries and graduate students came to observe this transformation. Of course, the results were soon obscured by the continuing avalanche of his new accumulation.

Happily, Gordon clung as closely to his friends and former students as he did to the material that never found its way to his waste basket.

Gordon was an indispensable figure in the evolution of Santa Barbara Teachers College into UCSB, a major research center. He led the department at a pivotal period in its growth. In departmental governance, Gordon was a Jeffersonian democrat: his department was a democracy, not an oligarchy. Not fanatical about consensus, Gordon nevertheless thought it beneficial for his department, and worth spending some time to achieve. But at heart he was inherently conservative: he could leaven Jefferson with Burke. Favoring discipline and experience over consciousness raising, he resisted the more radical proposals urged by student activists of the 1960s and 1970s. Long after he had left the chair, he remained the department's memory and the guardian of its precedents. His command of the rules of departmental practice, most of which he had nurtured into existence, was astonishing.
Gordon was a caring, gentle man whose mentoring was warmly remembered in cards and letters sent by dozens of his students to mark his 80th birthday. He was a model as well for his colleagues, especially the junior faculty who were nurtured by his strong sense of fairness. While that sense may not have leveled all ranks - to borrow from Gordon's beloved Gilbert and Sullivan-it came close: in presiding over the department's relocation to a new building, he assigned office space on the basis of use rather than seniority. All department chairs will appreciate the grit it took to give a larger office to an assistant than to a full professor.

His optimistic, informal style was pervasive and hardly ever left him, even during his struggle with a debilitating stroke. One of the endearing attributes that sustained him in this trying period was the joy he always could find in small things: his quest for the perfect dessert remains the stuff of legend in UCSB food management circles.

Gordon Baker will be sorely missed. The strength of character so much admired by his friends, colleagues, and students is captured in one of his favorite quotations: "The teachers you seek: Truth, Wisdom and Strength ... They are all within you." He was preceded in death by his son Jefferson, and he leaves behind his wife June and his daughter Lesley.

\section{Stanley V. Anderson, Roger H. Davidson, John E. Moore, and Thomas Schrock University of California, Santa Barbara Don Balmer Lewis and Clark College}

\section{Sidney Baldwin}

Sid Baldwin, emeritus professor at California State University, Fullerton, passed away in December of 2003 following a long illness. He joined the faculty in 1967 and taught a wide variety of courses spanning most areas of public administration, public policy, and comparative politics. He was also very instrumental in the development of the University's Masters Program in Public Administration. He retired in 1991.

Sid was a careful and creative scholar who published a great deal at a time when teaching loads were quite 
high and few resources were available for scholarly work. His first book Poverty and Politics (University of North Carolina Press, 1968) won several awards and is still widely cited. His second, Public Administration: Government in Action (Charles E. Merrill Publishing Company, 1976), co-authored with the late Ivan Richardson, also a member of our faculty, was considered an important and innovative textbook. Sid also had an abiding interest in the Middle East; he traveling there frequently often as an emissary for local Jewish interests.

We remember Sid most as a dynamic and creative teacher who was beloved by his students in spite of significant demands placed upon him. He employed diverse techniques and displayed an encyclopedic knowledge of both the science and art of his discipline. His students read novels, short stories, biographies, and plays in addition to the empirical works in the field. His student evaluations were always very high in spite of the complex readings and numerous writing assignments he required and evaluated with exacting rigor.

Sid earned a Bachelor's degree in Government from Wesleyan University, and a Masters and Doctorate in Public Administration from the Maxwell School at Syracuse University. We remember him perpetually in the form of the "Sidney Baldwin Award," given to the most outstanding MPA student each year.

$\mathrm{He}$ is survived by his wife Diana, two children, and four grand children. Sid was 81 when he passed away.

Alan Saltzstein California State University, Fullerton

\section{David Fellman}

At age 96, David Fellman died in Madison, Wisconsin, on November 23, 2003. During a long career, Fellman was widely known for distinguished scholarship and teaching in the field of public law, most notably for pioneering work on civil liberties, and for contributions to university government and academic freedom. He was deeply devoted to family and students, and institutionally to the University of Wisconsin and the American Association of University Professors. Prodigiously energetic during his professorial years, he remained active for two decades after retiring from the faculty in 1979.

Born in Omaha, Nebraska, on September 14, 1907, two years after his parents arrived as immigrants, Fellman was raised in an orthodox Jewish home in which biblical learning was fostered. He attended an academically rigorous Omaha public high school, and earned his way through the University of $\mathrm{Ne}$ braska mainly by teaching Hebrew in a religious school. Fellman received the B.A. (1928) and M.A. (1929) degrees at Nebraska, and the Ph.D. degree from Yale University in 1934. He returned to the University of Nebraska to teach from 1934 to 1947, and left for Wisconsin (now the University of WisconsinMadison) where he served as a professor for 32 years and as the holder of one of the University's prestigious Vilas chairs for the last 15 of those years.

His many journal articles and several books provided clear and concise expositions of legal cases, and sharp, often critical analyses of judicial opinions. Old timers will remember those qualities from his annual article on constitutional law, reviewing the prior year's work of the U.S. Supreme Court, that appeared in the American Political Science Review, 1949-1961.

Among his books are The Defendant's Rights (1958), The Limits of Freedom (1959), The Supreme Court and Education (1960), The Constitutional Right of Association (1963), Religion in American Public Law (1965), and The Defendant's Rights Today (1976). Fellman was president of the Midwest Political Science Association, 1955-1956; founding editor of that Association's Midwest Journal of Political Science (now American Journal of Political Science), 1957-1959; vicepresident of the American Political Science Association, 1959-1960; Senior Research Fulbright Fellow, Great Britain, 1961-1962; holder of research grants from the Fund for the Republic, 1957-1958, and the Social Science Research Council, 1959-1960; and recipient of an honorary degree from the University of Nebraska, 1966.

In his early faculty years, like most of his contemporaries, Fellman taught many courses-most often American political thought and introductory American government-in addition to those in his major field. But even before he concentrated on public law courses, students appreciated their stimulating and demanding character. He taught general constitutional law, administrative law, and civil liberties (which as a separate course was thought to be the first in an American political science department). Until at least the 1960s, in a practice resembling that of law school courses, Fellman expected students to be able to respond in class by briefing assigned cases. He is well-remembered not only by students who remained in political science, but also by the larger number who went on to become lawyers and who regarded Fellman as the teacher who first inspired their legal careers. Especially satisfying for Fellman, however, was the opportunity to teach and advise a succession of graduate students who subsequently had successful careers in political science and gratefully recalled his helpful dissertation supervision.

Without slackening his scholarship and teaching, Fellman was a very active citizen of his university, state, and academic profession generally. At Wisconsin, he served three years on the faculty's most influential University Committee, and as its chair 1962-1963. Later in the 1960s, Fellman chaired a rules codification committee and was a leader in the development of a Faculty Senate to displace a no longer feasible town-meeting of all faculty members. From 1971 to 1978 he chaired the Honorary Degrees Committee. Fellman is also remembered in the Madison community for his successful, though controversial, motion, in a 1960 faculty meeting, to abolish boxing at the University. That contribution was revisited in a local newspaper story at the time of Fellman's death. He wrote speeches for two Democratic governors in the 1960s, and was a member of the Governor's Commissions on Human Rights and of the Governor's Commission on Constitutional Revision.

Fellman had reason to be most proud of his national service in the cause of academic freedom. A member of the American Association of University Professors for 61 years, he was on its Committee A from 1957 to 1971 and chaired it from 1959 to 1964 , thus playing a major role in the Committee's traditional task of guarding academic freedom in the United States. Fellman became president of the AAUP in 1964-1966, and continued his AAUP service as a member of the Governing Board of its Legal Defense Fund into the 1990s.

Fellman's wife Sara died in 1994 after a marriage of 60 years. He is survived by two children, Laura and Michael, and by five grandchildren and two great grandchildren as well as by nieces and nephews. Hardworking though David was, he found time both for his family and for recreational activities. He and Sara enjoyed an active social life that involved a good deal of entertaining, and they both liked travel and music. David was also fond of baseball, indeed a long-suffering fan of the Chicago Cubs. Always interested in historical studies, David in his later years took special pleasure in reading the scholarly books on the American 